\title{
Faulty Instrument or Use of Instrument Artifact
}

National Cancer Institute

\section{Source}

National Cancer Institute. Faulty Instrument or Use of Instrument Artifact. NCI

Thesaurus. Code C87039.

An artifact resulting from the use of defective equipment or from improper use of equipment. 